\title{
Design of a Nuclear Desalination System - An Abundant Source of Fresh Water
}

\author{
Dheya Shuja'a Al-Othmany \\ Department of Nuclear Engineering, Faculty of Engineering, King Abulaziz University, Jeddah, Saudi Arabia
}

\begin{abstract}
Background and Objective: This research is based on conceptual design of single purpose desalination system by utilizing the Nuclear Energy so that the Sea water can be utilized for the use of industrial and potable purpose. Materials and Methods: The power required for the desalination of 2.6 MGPD is $40 \mathrm{MWth}$. The fuel used in the nuclear reactor is Uranium Dioxide $\left(\mathrm{UO}_{2}\right)$ with $3 \%$ enrichment. The coolant used is light water $\left(\mathrm{H}_{2} \mathrm{O}\right)$ which is also used in the intermediate looping. To slow the fast neutrons to thermal energy, the moderator used is also the light water. Multi-Effect Desalination (MED) process is considered as a process of desalination after analyzing various quality and economic benefits.

Results: The fuel was designed and arranged in the core using 4 assemblies with each assembly having a matrix of $15 \times 15$ fuel rods. The thermal designed of this study is based on the standards as mentioned by the International Atomic Energy Agency (IAEA). The core neutronics and thermal parameters resulted in $3 \%$ enriched fuel of $\mathrm{UO}_{2}$. Conclusion of the Study: On the basis of numerical analysis using the similar conditions the parameters like $\mathrm{He}$ layer thickness, cladding thickness of Zircalloy material, length of fuel rods and coolant bulk temperature were adopted. By executing the necessary design calculations, the nuclear reactor design was finalized which is meant only for heating purpose.
\end{abstract}

Keywords: nuclear energy, desalination system, design calculations, fuel rods, MED

DOI: $10.7176 /$ APTA/77-05

Publication date:May $31^{\text {st }} 2019$

\section{INTRODUCTION}

Fresh water is emerging as the most critical resource issue facing humanity. While the supply of fresh water is limited, both the world's population and demand for the resource continues to expand rapidly. The world's rapid population growth over the last century has been a major factor in increasing global water usage. Caught between (a) finite and increasingly polluted water supplies, and (b) rapidly rising demand from population growth and development, many developing countries face difficult and uneasy choices. Population and water resources are closely connected. At some point, however, this increased demand becomes overuse, leading to depletion and pollution of surface and groundwater supplies that can cause chronic water shortages. In less than 30 years, 50 countries could face serious water shortages, affecting more than 3.3 billion people - 40 percent of the projected global population ${ }^{1-3}$.

Saline Water can be turned into fresh water via process named as "Desalination" which is also the basic theme of this project. It is not a modern science. Desalination/distillation is one of mankind's earliest forms of water treatment, and it is still a popular treatment solution throughout the world today. The basic process of desalination is that Saline water is taken and is provided heat which evaporates the water, this water then comes in contact with the cooled air where it re-condenses to form dew or rain and hence water is now free from salt. The process of Desalination can be employed on an Industrial and Commercial level. There are number of ways to provide the heat for the desalination of saline water namely by utilizing the Sun energy, by the combustion of Natural gas and then utilizes its heat, by the combustion of Coal. One the most economic method for this purpose is the "Nuclear Desalination" method which is also the title of this project. The most important users of this method are in the Middle East, (mainly Saudi Arabia, Kuwait, the United Arab Emirates, Qatar and Bahrain), which uses about 70\% of worldwide capacity; and in North Africa (mainly Libya and Algeria), which uses about $6 \%$ of worldwide capacity ${ }^{4-6}$.

Within the last decade or more, there has been a growing interest in using nuclear energy for the desalination purpose. Some feasibility studies conducted by the IAEA have proven the viability of using nuclear energy as a source to desalination from an economic and technical perspective. The nuclear desalination consists of two parts; nuclear unit and desalination unit. Sometimes the desalination unit is accompanied with unit of electrical generation so that a fraction of the thermal energy generated from the reactor is utilized to generate electrical power. Nuclear power shares $16 \%$ of the electricity in the world within 30 countries. In last 5 decades, about 10,000 reactor-years of operation have been experienced. Recently, the idea of merging desalinating seawater with producing electrical power by nuclear option has been thought of to overcome the water shortage. Globally, over 175 reactor-years of operation experience on nuclear desalination have been accumulated. IAEA supports progresses on nuclear desalination programs to investigate its economic and technical viability ${ }^{7-8}$.

When it comes to the fuel combustion, fossil fuel combustion results in producing large toxic emissions and 
greenhouse gases while on the other hand nuclear does not produce those harmful gases and emissions. Based on the Mediterranean studies, by 2020 there will be about 10,000,000 $\mathrm{m}^{3} /$ day of water additional need to be produced. The important feature to know is that when this additional amount of water is covered by nuclear desalination, there will be reduction of almost $200000000 \mathrm{t} /$ year of $\mathrm{CO}_{2}, 200000 \mathrm{t} /$ year of $\mathrm{SO}_{2}, 60000 \mathrm{t} /$ year of $\mathrm{NO}_{2}, 16000$ $\mathrm{t} /$ year of other hydrocarbons. Desalination process provides two product of water. Among them one is of higher concentration than the original feed water known as brine concentrate or concentrate, the other one with lower concentration then the feed water called fresh water ${ }^{9-11}$.

\section{DESIGN ANALYSIS}

Power generation in a reactor core is limited to thermal characteristics rather than nuclear properties as neutronflux has no limit i-e the work is needed only to remove heat generated.

Rate of heat generation is directly related to rate of reaction, and rate of reaction is given as:

And thus rate of heat generation is given as,

$$
\mathrm{R}=\in \varphi
$$

$$
\begin{gathered}
\mathrm{q} ",=\mathrm{GR} \quad ; \in=\sigma \mathrm{N} \\
\mathrm{q}^{\prime \prime \prime}=\mathrm{G}_{\mathrm{f}} \mathrm{N}_{\mathrm{ff}} \sigma_{\mathrm{f}} \varphi
\end{gathered}
$$

Where

q"'= volumetric source strength

$\mathrm{G}=$ energy per reaction

$\mathrm{N}=$ fissionable fuel density

$\sigma_{\mathrm{f}}=$ microscopic cross section

$\varnothing=$ neutron flux

The volumetric thermal source strength at any one position in a core is directly proportional to the neutron flux at that position. A fuel element is usually situated vertically in a heterogeneous core such that its length is equal to height of the core. The fuel cross section area is so small compare to that in the core that the radial variation in the flux is negligible. The axial variation in flux is taken into account and the neutron flux drops to zero at some extrapolated height $\mathrm{He}$, i.e. $\varnothing=0$ at $\mathrm{z}= \pm \mathrm{He} / 2$. If the variation of neutron flux in axial direction is pure cosine function of $\mathrm{z}$ the maximum value of $\varnothing$ and $\mathrm{q} "$ " occurs at the center. Other fuel elements closer to the center of the core normally have higher values of neutron flux and $\mathrm{q}_{\mathrm{c}}{ }^{\prime \prime}$. It is to be indicated here that when the reactivity varied with $\mathrm{z}$, because of a large axial temperature rise in a water-moderated core or because of change in phase, such as in the boiling water reactor or in fuel enrichment because of uneven burn up, or because of partially inserted control rods, the axial flux may deviate appreciably from the cosine function. In such cases some other relationship between q", and $\mathrm{z}$ can be used in the analysis ${ }^{12}$.

Using the Heat Conduction Equation

$$
\begin{gathered}
\left(U^{\phi+\Delta \phi}-U^{\phi}\right)=(q x+q y+q z) \Delta \phi-(q x+\Delta x+q y+\Delta y+q z+\Delta z) \Delta \phi-(q x+\Delta x+q y+\Delta y \\
+q z+\Delta z) \Delta \phi \\
-(q x+\Delta x+q y+\Delta y+q z+\Delta z) \Delta \phi+\left(\Delta x \Delta y \Delta z q^{\prime \prime \prime}\right) \Delta \phi
\end{gathered}
$$

After simplifying using assumptions we get;

$$
\frac{\delta^{2} t}{\delta X^{2}}+\frac{\delta^{2} t}{\delta Y^{2}}+\frac{\delta^{2} t}{\delta Z^{2}}+\frac{q^{\prime \prime \prime}}{k}=\left(\frac{1}{\alpha}\right) \cdot\left(\frac{\delta t}{\delta \phi}\right)
$$

In cylindrical or polar coordinates:

$$
\nabla^{2} t=\frac{\delta^{2} t}{\delta r^{2}}+\left(\frac{1}{r}\right) \cdot\left(\frac{\delta t}{\delta r}\right)+\left(\frac{1}{r^{2}}\right) \cdot\left(\frac{\delta^{2} t}{\delta r^{2}}\right)+\frac{\delta^{2} t}{\delta Z^{2}}
$$

In one dimensional case:

In cylindrical or polar coordinates:

$$
\nabla^{2} t+\frac{q^{\prime \prime \prime}}{k}=\left(\frac{1}{\alpha}\right) \cdot\left(\frac{\delta t}{\delta \phi}\right)
$$

$$
\nabla^{2} t=\frac{d^{2} t}{d r^{2}}+\left(\frac{2}{r}\right)\left(\frac{d t}{d r}\right)
$$

The amount of reactor power generation in a given reactor is limited by thermal rather than by nuclear considerations. The reactor core must be operated at such a power level that with the best available heat-removal system, the temperatures of the fuel and cladding anywhere in the core must not exceed safe limits ${ }^{13}$.

Reactor cores are usually limited by those parameters that cause the temperatures to exceed safe limits. In liquid-cooled reactors theses may be the burnout heat flux, which affects the cladding surface. In gas-cooled reactors the relatively low heat-transfer coefficients would pose limitations on the fuel centerline or cladding temperatures. Before starting this calculation it should be noted that we have been defined our reactor power to be of $40 \mathrm{MW}$ and fuel enrichment to be of $3 \%$. Further we shall be using $15 \times 15$ matrixes. The fuel cycle length is set 
fuel to 2.5 years i-e after this period the fuel burn up will occur ${ }^{14-16}$.

As it is evident that only element $\mathrm{U}_{235}$ is responsible for fission and oxygen in $\mathrm{UO}_{2}$ will not take part in fission i-e so the total thermal power shall be obtained from uranium $U_{235}$ element ${ }^{17}$.

Since, $1 \mathrm{Watt}=3.12 \times 10^{10}$ fissions $/ \mathrm{sec}$

$$
40 \mathrm{MW}=1.248 \times 10^{18} \text { fissions/sec }
$$

For fuel cycle time of 2.5 years we require

Total No of fissions $=9.828 \times 10^{25}$

For each fission reaction, we require $\mathrm{U}^{235}$ atom (Ignoring fast fission in $\mathrm{U}^{238}$ )

Total no of $U^{235}$ atoms required $=9.828 \times 10^{25}$

Since the fuel is $3 \%$ enriched

$$
\text { Total no of Uranium atoms }=\frac{9.828 \times 1025}{0.03}
$$

Total no of Uranium atoms $=3.276 \times 10^{27}$

Each $\mathrm{UO}_{2}$ molecule contains 1 Uranium atom

Total no of $\mathrm{UO}_{2}$ molecules $=3.276 \times 10^{27}$

The purpose of moderator is to convert all the fast neutrons to thermal neutrons. Thus there is a relation between number of fissions and number of hydrogen atom,

Number of Hydrogen Atoms $=524 \times 9.828 \times 10^{25}$

Number of Hydrogen Atoms $=5.14 \times 10^{28}$ atoms

Since each oxygen atom is combined with two hydrogen atom therefore the number of $\mathrm{H}_{2} \mathrm{O}$ molecules would be ,

\section{Number of $\mathrm{H}_{2} \mathrm{O}$ Molecules $=2.57 \times 10^{28}$ molecules}

The basic principle for finding fuel and moderator volume is to know the atom density for each. Dividing molecules by atom density gives volume. The fuel volume is utilized in recognizing the rod volume and utilize the moderator volume to recognize pitch of the cell ${ }^{18-20}$.

Volume of Fuel is determined as

$$
\begin{aligned}
& N_{U O 2}\left(\frac{\text { molecules }}{\mathrm{cm}^{3}}\right) \\
& =6.02 \times 10^{23} \frac{\text { molecule }}{\text { mole }} \times \frac{10.97 \frac{\mathrm{g}}{\mathrm{cm}^{3}}}{238 \frac{\mathrm{g}}{\text { mole }} \times 0.97+235 \frac{\mathrm{g}}{\text { mole }} \times 0.03+16 \frac{\mathrm{g}}{\text { mole }} \times 2} N_{U 02}\left(\frac{\text { molecules }}{\mathrm{cm}^{3}}\right) \\
& \mathrm{N}_{\text {uo2 }}\left(\frac{\text { molecules }}{\mathrm{cm}^{3}}\right)=2.446 \times 10^{22} \\
& \text { Volume of } \mathrm{UO}_{2}=3.27 \times 10^{27} / 2.44 \times 10^{22} \\
& =133932.95 \mathrm{~cm}^{3}
\end{aligned}
$$

Similarly, amount of fuel required can be calculated as,

Mass of $\mathrm{UO}_{2}=$ density $\mathrm{x}$ volume

Mass of $\mathrm{UO}_{2}=10.97 \times 133932.95$

Mass of $\mathrm{UO}_{2}=1469244.462 \mathrm{gm}$

Mass of $\mathrm{UO}_{2}=1469.2444 \mathrm{Kg}$

Volume of Moderator is determined as

$$
\begin{aligned}
N_{H 2 O} & =6.02 \times \frac{10^{23} \text { molecules }}{\text { mole }} \times \frac{1 \frac{\mathrm{g}}{\mathrm{cm}^{3}}}{(2 \times 1+16) \frac{\mathrm{g}}{\text { mole }}} \\
& =3.34 \times 10^{22} \text { molecules } / \mathrm{cm}^{3}
\end{aligned}
$$

Total moderator volume needed is $\mathrm{V}_{\mathrm{H} 2 \mathrm{O}}$ :

$$
\begin{aligned}
& V_{H 2 O}=\frac{H 2 O \text { molecules }}{N_{H 2 O}} \\
& V_{H 2 O}=\frac{2.57 \times 1028}{3.34 \times 1022} \\
& =770938.922 \mathrm{~cm}^{3} \\
& V_{H 2 O}=0.77 \mathrm{~m}^{3}
\end{aligned}
$$

A unit cell is an arrangement of four quarters of four rods separated by the pitch distance. Therefore, it is known that each cell contains one rod (4 quarters). Because each unit cell does represent one rod therefore the number of unit cells will be equal to the number of rods. Coolant will flow in the area between the four quarters ${ }^{21-22}$. Number of unit cells (channels) = number of fuel rods

Each quarter from each rod will represent one rod that belongs to the channel 


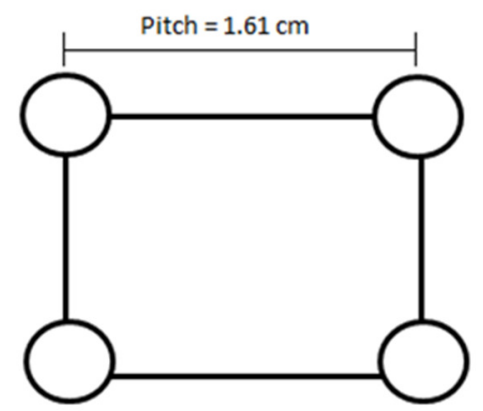

Figure1: Unit cell arrangement

Since the assembly is $15 \times 15$ i-e 225 rods per assembly,

NO. of assemblies $=4$

Volume of fuel per rod per assembly $=133932.5 / 225 \times 4$

$$
=148.814 \mathrm{~cm}^{3}
$$

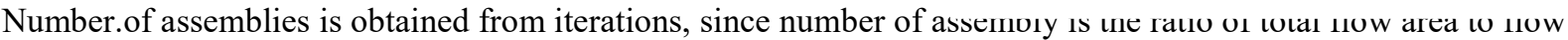
area per assembly. Now,

Height of $\operatorname{rod}=4 \mathrm{~m}$

$\mathrm{V}_{\text {rod }}=\pi / 4 \mathrm{D}^{2} \times \mathrm{H}$

$148.814=\pi / 4 \mathrm{D}^{2} \mathrm{x} 400$

Diameter of pellet $=0.688 \mathrm{~cm}$

Using numerical analysis, following data has been found compatible with the chosen configuration of fuel rod. Using uranium dioxide as fuel therefore it is needed to use helium layer between fuel and cladding in $\operatorname{rod}^{23}$.

1. Thickness of He layer $=4.128 \times 10^{-3} \mathrm{~cm}=1.35 \times 10^{-4} \mathrm{ft}$

2. Thickness of Zircalloy (cladding) $=0.041 \mathrm{~cm}=1.345 \times 10^{-3} \mathrm{ft}$

Therefore:

Total outer radius of $\mathbf{r o d}=0.688 / 2+0.041+4.128^{-3}=\mathbf{0 . 3 8 9} \mathbf{~ c m}$

Now, we need to find pitch length which can be calculated as follows:

Volume of Moderator per Channel $=\mathrm{P}^{2} \times \mathrm{H}-\frac{\pi x D^{2} * H}{4}$

$$
\begin{aligned}
& \frac{0.77}{4 \times 225 \times 4 \mathrm{~m}}=\mathrm{P}^{2}-\frac{3.142}{4}\left(2 \times 0.389 \times 10^{-2}\right)^{2} \\
& \mathrm{P}=0.0161 \mathrm{~m} \\
& \mathbf{P}=\mathbf{1 . 6 1 \mathrm { cm }}
\end{aligned}
$$

Neutron flux at the core center can be evaluated as,

Using heat generation equation

$$
q=\int_{V} \operatorname{Er} \Sigma_{f} \phi(r, \theta, \mathrm{z}) d V
$$

Where;

$\mathrm{Er}=$ fission energy $=180 \mathrm{MeV}$.

$\mathrm{E}_{\mathrm{r}}=180(\mathrm{MeV}) \times 1.6 \times 10^{-13} \frac{\mathrm{J}}{\mathrm{MeV}}$

$\Sigma_{\mathrm{f}}=$ macroscopic cross section fission (cm-1).

$\sum_{\mathrm{f}}=\mathrm{N}_{\mathrm{f}} * \sigma_{\mathrm{f}}$

$$
\begin{aligned}
& \mathrm{N}_{\mathrm{f}}=\mathrm{A}_{\mathrm{v}} \frac{\rho . r}{A w} \\
& \text { Where; } \\
& \left.\mathrm{N}_{\mathrm{f}}=\text { fission atom density (nuclei } / \mathrm{cm} 3\right) \\
& \rho=\text { density for Uranium }=19.1 \mathrm{~g} / \mathrm{cm} 3 \\
& \mathrm{r}=\text { enrichment }=0.03 \\
& \mathrm{Av}=\text { Avogadro's number }=0.6022 \times 1024 \text { atoms } / \text { mole. } \\
& \mathrm{Aw}=\text { atomic weight }=235 \\
& \mathrm{~N}_{\mathrm{f}}=6.02 \times 10^{23} \frac{(19.1)(0.03)}{235} \\
& \mathrm{~N}_{\mathrm{f}}=1.46 \times 10^{21} \text { atoms } / \mathrm{cm} 3 \\
& \text { For } \mathrm{U}^{235} ; \\
& \sigma_{\mathrm{f}}=587 \text { barn }=587 \times 10^{-24} \mathrm{~cm}^{-3}
\end{aligned}
$$


$\varnothing=$ space flux $[\mathrm{n}$ 's $/(\mathrm{cm} 2 \mathrm{sec})]$.

$\varnothing(\mathrm{r}, \theta, \mathrm{z})=\emptyset_{\mathrm{co}} \mathrm{J}_{\mathrm{o}}\left(\frac{2.405 r}{R}\right) \cos \left(\frac{\pi z}{H}\right)$

Therefore;

$\mathrm{q}=\left(180 \times 1.6 \times 10^{-13}\right)\left(1.46 \times 10^{21} \times 587 \times 10^{-24}\right) \int_{-H / 2}^{H / 2} \int_{0}^{2 \pi} \int_{0}^{R}\left(\varnothing_{\operatorname{co}} \mathrm{J}_{\mathrm{o}}\left(\frac{2.405 r}{R}\right) \cos \left(\frac{\pi z}{H}\right) \mathrm{drd} \theta \mathrm{dz}\right.$

$\mathrm{q}=2.46 \times 10^{-11} \int_{-H / 2}^{H / 2} \int_{0}^{2 \pi} \int_{0}^{R}\left(\varnothing_{\mathrm{co}} \mathrm{J}_{\mathrm{o}}\left(\frac{2.405 r}{R}\right) \cos \left(\frac{\pi z}{H}\right) \mathrm{drd} \theta \mathrm{dz}\right.$

$\mathrm{q}=2.46 \times 10^{-11} \emptyset_{\mathrm{co}}\left\{\int_{-\frac{H}{2}}^{\frac{H}{2}} \cos \left(\frac{\pi z}{H}\right) \mathrm{dz}\right\}\left\{\int_{0}^{2 \pi} d \theta\right\}\left\{\int_{0}^{R} J\left(\frac{2.405}{R}\right) r d r\right\}$

$\mathrm{q}=2.46 \times 10^{-11} \emptyset_{\mathrm{co}}\left\{\left|\frac{-H}{2 \pi} \sin \frac{\pi z}{H}\right| \begin{array}{c}H / 2 \\ -H / 2\end{array}\right\}\left\{|\theta|_{0}^{2 \pi}\right\}\left\{\left|\frac{R}{2.405} \cdot r J\left(\frac{2.405 r}{R}\right)\right|_{o}^{R}\right\}$

$\mathrm{q}=2.46 \times 10^{-11} \emptyset_{\operatorname{co}}\left\{\frac{H}{\pi} \sin \left\{\frac{\pi}{H}\left(\frac{H}{2}\right)\right\}-\sin \left\{\frac{\pi}{H}\left(\frac{-H}{2}\right)\right\}\right\}\{2 \pi\}\left\{\frac{R}{2.405} \cdot r J\left(\frac{2.405 r}{R}\right)\right\}$

$\mathrm{q}=2.46 \times 10^{-11} \emptyset_{\text {co }}\left\{\frac{H}{\pi} \cdot 2 \sin \left(\frac{\pi}{2}\right)\right\}\{2 \pi\}\left\{\frac{R}{2.405} \cdot R J(2.405)\right\}$

$\mathrm{q}=2.46 \times 10^{-11} \emptyset \operatorname{co}\left\{(2 \pi)\left(\frac{H}{\pi}\right)\left(\frac{R}{2.405}\right)\right\}\left\{2 \sin \frac{\pi}{2} \cdot R J(2.405)\right\}$

From table;

$\mathrm{J}(2.405)=0.5202$

$\mathrm{q}=2.46 \times 10^{-11}\left\{2 \pi \cdot \frac{1}{\pi} \cdot \frac{1}{2.405} \cdot(2)(1)(0.5202)\right\} \varnothing_{\text {co }} \mathrm{R}^{2} \mathrm{H}$

$q=2.12 \times 10^{-11} \emptyset_{c o} R^{2} H$

Since,

$\mathrm{q}=40 \times 10^{6} \mathrm{~W}$

$\mathrm{R}=77.23 / 2 \mathrm{~cm}$

$\mathrm{H}=4 \mathrm{~m}=400 \mathrm{~cm}$

Therefore,

$\varnothing_{\mathrm{co}}=3.16 \times 10^{12} \frac{\text { nuclei }}{\mathrm{cm}^{\wedge} 2 . s e c}$

The thermal hydraulic calculations are mainly based on coolant flow in channels. The heat obtained from fuel must be transferred to the pressurized coolant, this heat transferred is mainly concerned with the desalination capability as in intermediate looping this amount of heat will be required to produce steam that runs our desalination system. Coolant flow in channel must be accurately calculated so that the fuel has to be arranged in a way that guarantees achieving our purpose ${ }^{24}$.

Since coolant will flow through the channels, extracting heat from the fuels therefore care should be taken in setting the pressure as it would be hazardous if the coolant boils so for this reason we have utilized the standard parameters of PWR by setting pressure of $16 \mathrm{MPa}$ and bulk fluid temperature of about 322 degree Celsius.

$$
\begin{array}{rll}
\text { Primary Coolant Flow } & = & \frac{q}{h 2-h 1} \\
& = & \frac{40 \times 103}{93.401} \\
\text { Primary Coolant Flow } & = & \mathbf{4 2 8 . 2 6} \mathbf{~ k g} / \mathrm{s}
\end{array}
$$

\section{RESULTS AND DISCUSSIONS}

Using iterations and thermal analysis, it is found that there would be 4 assemblies in the system each with 225 fuel rods. The fuel rod content is a disk of fuel pellet surrounded by cladding material with small gap between them filled with Helium gas.

Fuel Pellet

Cladding

He Layer

$$
3 \% \text { enriched } \mathrm{UO}_{2}, 0.688 \mathrm{~cm} \text { diameter and } 1.5 \mathrm{~cm} \text { long. }
$$

Zircaloy 2 is a cladding material of thickness $0.041 \mathrm{~cm}$ or $1.345 \times 10^{-3} \mathrm{ft}$.

Diametrical clearance between pellet and

Cladding is $4.128 \times 10^{-3} \mathrm{~cm}=1.35 \times 10^{-4} \mathrm{ft}$, which is filled with Helium.

Thus, Outside diameter of fuel rod is $\mathbf{0 . 3 8 9} \mathbf{~ c m}$. 


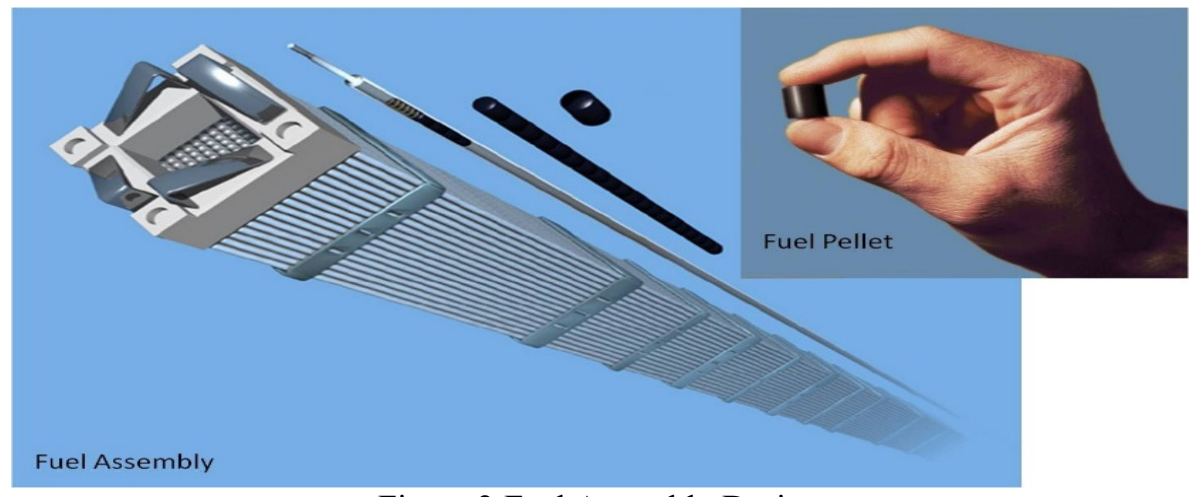

Figure 2:Fuel Assembly Design

Pitch is the distance between centers of two rods. Size of the assembly is the distance that is separated by the centers of two rods located at two apparent corners of the assembly. Assembly pitch is one line out the four that make the squared assembly that contains the rods inside $\mathrm{it}^{25}$.

$$
\begin{aligned}
& \text { Volume of Moderator per Channel }=\mathrm{P}^{2} \times \mathrm{H}-\frac{\pi x D^{2} * H}{4} \\
& \frac{0.77}{4 \times 225 \times 4 \mathrm{~m}}=\mathrm{P}^{2}-\frac{3.142}{4}\left(2 \times 0.389 \times 10^{-2}\right)^{2} \\
& \mathrm{P}=0.0161 \mathrm{~m} \\
& \mathbf{P}=\mathbf{1 . 6 1 \mathrm { cm }}
\end{aligned}
$$

1. Assembly pitch $=15($ dia of rod $)+14($ pitch $)$

Assembly pitch $=34.21 \mathrm{~cm}$

$$
=15(2 \times 0.389)+14(1.61)
$$

2. Gross area $=($ assembly pitch $) 2$

Gross area $=1170.324 \mathrm{~cm}^{2}$

3. Fuel Rods Area per Assembly $=\mathrm{n} \times \frac{\pi * \text { (dia of a single rod }) 2}{4}$

Fuel Rods Area per Assembly $=225 \times \frac{\pi x(2 \times 0.389) 2}{4}$

Fuel Rods Area per Assembly $=106.962 \mathbf{c m}^{2}$

4. Flow area per assembly $=$ Gross area - fuel rods area per assembly

Flow Area per assembly $=1063.362 \mathrm{~cm}^{2}$

1. Volumetric Coolant Flow Rate $=$ Primary Coolant Flow x Specific Volume

$$
\begin{aligned}
\text { a } 322^{\circ} \mathrm{C} \text { Specific Volume } & =0.0015 \mathrm{~m}^{3} / \mathrm{kg} \\
\text { Primary Coolant Flow } & =\frac{q}{h 2-h 1} \\
& =\frac{40 \times 103}{93.401} \\
\text { Primary Coolant Flow } & =\mathbf{4 2 8 . 2 6} \mathbf{~ k g} / \mathrm{s}
\end{aligned}
$$

Volumetric Coolant Flow Rate $=428.26 \times 0.0015$

Volumetric Coolant Flow Rate $=0.642 \mathrm{~m}^{3} / \mathrm{s}$

2. At operating conditions flow velocity is found to be $\mathbf{4 2 0 . 1 7 2} \mathbf{~ c m} / \mathbf{s}$

3. Total coolant flow area $=\frac{\text { volumetric coolant flow rate }}{\text { flow velocity }}=\frac{642390}{420.172}$

Total coolant flow area $=0.152 \mathrm{~m}^{2}$

The arrangement of the Core is as follows:

1. Total Core Area $=$ No. of Assembly x (Pitch Assembly Area $)^{2}$

$$
=4 \times(34.21)^{2}
$$$$
A_{\text {core }}=4681.296 \mathrm{~cm}^{2}
$$

2. Equivalent dia. of core:

$$
\begin{gathered}
\text { Area }=\frac{\pi}{4} \times D_{\mathrm{e}}{ }^{2} \\
D_{\mathbf{e}}=\mathbf{7 7 . 2 0 3} \mathrm{cm}
\end{gathered}
$$

3. $\mathrm{L} / \mathrm{D}$ ratio $=\mathbf{5 . 1 8}$ 
Now,

- $\quad$ Net Core Volume $=$ Total Core Area $x$ Fuel Rod Length $=4681.296 \times 400$

$=1.855 \times 10^{6} \mathrm{~cm}^{3}$

Net Core Volume $=\mathbf{1 8 7 2 . 5}$ liter

$$
\begin{aligned}
& \text { Net Heat Release/Unit Volume }=\frac{\text { Reactor Heat Power }}{\text { Net Core Volume }} \\
& =\frac{40 \times 103}{1.872 \times 106} \\
& =0.021 \mathrm{~kW} / \mathrm{cm}^{3} \\
& =21.36 \mathrm{KW} / \text { liter }
\end{aligned}
$$

The maximum temperature in fuel, the cladding inner and outer temperature and ensure the safe operation.

Max. Power density is assumed to be $\mathbf{3 5 8 . 2 7} \mathbf{W} / \mathbf{c m}$ length of fuel rod.

Thus, average power density is $=1 / 4(\max$. power density $)=\mathbf{8 9 . 5 6} \mathbf{w} / \mathbf{c m}$

Heat flux $=\frac{\text { Max.power density }}{\text { fuel rod perimeter }}=\frac{358.27}{3.142(0.778)}$

\section{Heat flux $=146.582 \mathrm{~J} / \mathrm{cm}^{2} . \mathbf{s e c}$}

Coolant film coefficient

Using Dittus Boelter equation ${ }^{26}$.

$$
\begin{aligned}
\mathrm{h}=8 \times 10^{-5} & \left(1+10^{-2} \mathrm{~T}-10^{-5} \mathrm{~T}^{2}\right) \times \frac{v^{\wedge} 0.8}{D^{\wedge} 0.2} \\
; \mathrm{T} & =322.5 \mathrm{C}=612.5 \mathrm{~F} \\
\mathrm{~V} & =49626.614 \mathrm{ft} / \mathrm{hr} \\
\mathrm{D} & =4 \times\left(\frac{\text { fuel assembly coolant flow area }}{\text { total fuel rod perimeter }}\right)=\frac{4 \times 1063.362}{3.142 \times 0.778 \times 225} \\
\mathrm{D} & =0.253 \mathrm{ft}
\end{aligned}
$$

Thus,

$$
\mathrm{h}=2.028 \mathrm{~J} / \mathrm{cm}^{2} . \mathrm{sec} . \mathrm{C}=20280 \mathrm{~W} / \mathrm{m}^{2} . \mathrm{C}
$$

$1 \mathrm{~W} / \mathrm{m}^{2} . \mathrm{C}=0.176228 \mathrm{Btu} / \mathrm{hr}^{.} \mathrm{ft}^{2}{ }^{\circ} \mathrm{F}$

$$
\text { h }=3573.9 \mathrm{Btu} / \mathrm{hr} . \mathrm{ft}^{2}{ }^{\circ} \mathrm{F}
$$

$$
\mathrm{q}=\frac{136.48 \times 10^{6}}{4 \times 225}=151.64 \times 10^{3} \mathrm{Btu} / \mathrm{hr}
$$

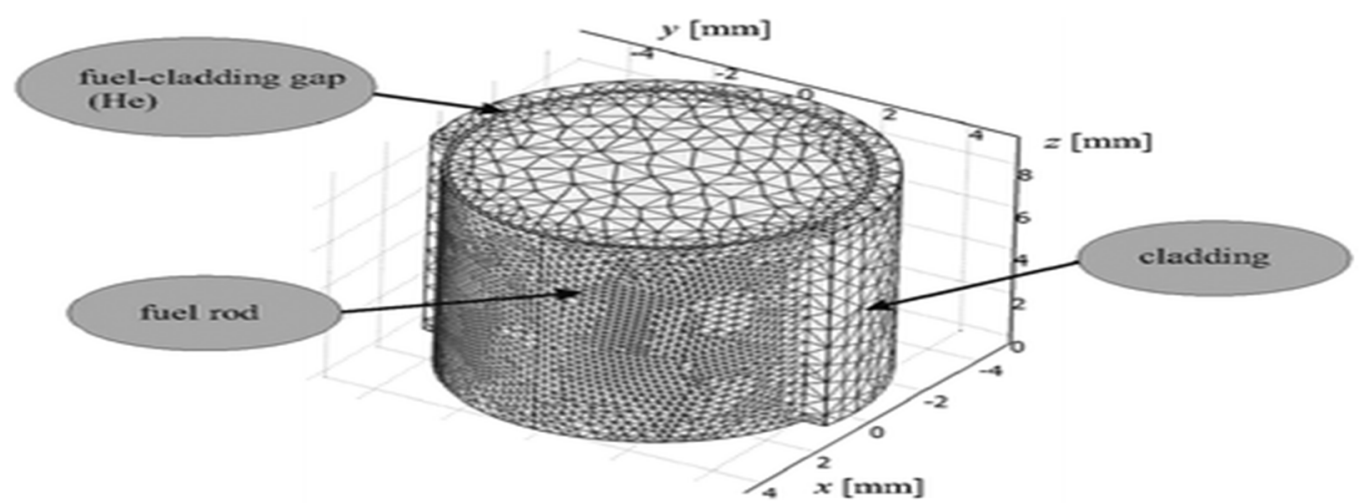

Figure 3: Thermal Design of fuel element ${ }^{27}$

$$
\begin{aligned}
& \mathrm{q}=\frac{T m-T f}{\frac{R}{2 \cdot K f \cdot A r}+\frac{c}{K c \cdot A m}+\frac{c_{H e}}{K_{H e} \cdot A_{H e}}+\frac{1}{h \cdot A_{R+C}+C_{H e}}} \\
& A_{r}=2 \pi R l=0.927 f t^{2} \\
& A_{m}=\frac{2 \pi c l}{\ln \left(\frac{R+c}{R}\right)}=0.984 f t^{2}
\end{aligned}
$$

$A_{H e}=2 \pi\left(\mathrm{R}+C_{H e}\right) \mathrm{L}=0.9412 f t^{2}$

$A_{R+C+C_{H e}}=2 \pi\left(\mathrm{R}+\mathrm{C}+C_{H e}\right) \mathrm{L}=1.052 f t^{2}$ 
For Max. Midpoint Temperature

Applying all values to above Eq.:

$$
\begin{aligned}
& 151,6410^{3}=\frac{T m-611.6}{0.927+0.984+0.9412+1.052} \\
& \mathbf{T m}=\mathbf{1 7 6 9 . 3 2 5}^{\circ} \mathrm{F}=\mathbf{9 6 5 . 1 8}^{\circ} \mathrm{C}
\end{aligned}
$$

For Inner Cladding Temperature

$$
\mathrm{q}=\frac{T m-T c 1}{\frac{R}{2 . K f . A r}+\frac{c_{\mathrm{He}}}{\boldsymbol{K}_{\mathrm{He} \cdot \boldsymbol{A}_{\mathrm{He}}}}}
$$

$\mathrm{Tc}_{1}=\mathbf{6 7 7 . 8 2}^{\circ} \mathrm{F}=358.78^{\circ} \mathrm{C}$

For Outer Cladding Temperature

$$
\begin{gathered}
\mathrm{q}=\frac{T m-T c 2}{\frac{R}{2 . K f \cdot A r}+\frac{c}{K c . A m}+\frac{c_{H e}}{K_{H e} \cdot A_{H e}}} \\
T \mathrm{c}_{2}=651.92^{\circ} \mathrm{F}=344.4^{\circ} \mathrm{C}
\end{gathered}
$$

Since outer cladding temperature is less than the Melting point of Zircaloy 2 i-e $3310^{\circ} \mathrm{F}$

Therefore, Design is safe.

$$
q=h \times A \times\left(T_{s}-T_{a}\right)
$$

$\mathbf{T a}=\mathbf{T}_{\mathrm{f} 2}=321.89^{\circ} \mathrm{C}$ i.e. coolant outlet temperature.

Setting the pressure at $16 \mathrm{MPa}$ to avoid boiling.

Since $\mathrm{T}_{\text {sat }} @ 16 \mathrm{MPa}$ is $347.44^{\circ} \mathrm{C}$, which is greater than coolant temperature.

Hence the design is safe.

\section{CONCLUSIONS}

The design calculations were done for a nuclear reactor, which is capable of producing fresh water amounting to 2.6 MGPD that is equivalent to $114 \mathrm{~kg} / \mathrm{s}$. The design data collected and studied the using various literature sources gave good idea about the design of nuclear reactor operations, numerical analysis regarding nuclear heat generation and thermal design. The design calculations were performed in details to evolve the core neutronics and thermal design. For a $40 \mathrm{MW}$ (thermal) nuclear reactor. A matrix of $15 \times 15$ and fuel i.e. $3 \%$ enriched $\mathrm{UO}_{2}$ for fuel element was finalized. On the basis of numerical analysis using the similar conditions the selection related to the design parameters like $\mathrm{H}_{\mathrm{e}}$ layer thickness, cladding thickness of Zircalloy material, length of fuel rods and coolant bulk temperature.

Significance of the study: Understanding related to the design of a nuclear reactor, core neutronics and thermal design were acquired during this research. By executing the necessary design calculations, a nuclear reactor design is finalized which is used for heating purpose only.

\section{REFERENCES}

[1] M.H.I. Dore, (2005), Forecasting the economic costs of desalination technology, Desalination, 172, $207-214$. doi: 10.1016/j.desal.2004.07.036

[2] E. Delyianni and B. Belessiotis, 1995, Methods and Desalination Systems - Principles of the Desalination Process, NCSR "Demokritos”, Athens, Greece. doi:10.1016/j.desal.0000.00.000

[3] S.A. Avlonitis, 2002, Operational water cost and productivity improvements for small-size RO desalina- tion plants, Desalination, 142, 295-304. DOI: 10.1016/S0011-9164(02)00210-2

[4] D.P. Rico and M.F.C. Arias, 2001, A reverse osmosis potable water plant at Alicante University: first years of operation, Desalination, $137,91-102$. doi:10.1016/j.desal.0000.00.000

[5] M.D. Afonso, J.O. Jaber and M.S. Mohsen, 2004, Brackish groundwater treatment by reverse osmosis in Jordan, Desalination, 164, 157-171.DOI:10.1016/S0011-9164(04)00175-4

[6] I.C. Karagiannis and P.G. Soldatos, 2007, Current sta- tus of water desalination in the Aegean Islands, Desalination, 203, 56-61.https://doi.org/10.1016/j.desal.2007.02.071

[7] Y. Al-Wazzan, M. Safar, S. Ebrahim, N. Burney and A. Mesri, 2002, Desalting of subsurface water using spiral-wound reverse osmosis (RO) system: tech-nical and economic assessment, Desalination, 143, 21-28. https://doi.org/10.1016/S0011-9164(02)00217-5

[8] Al Wakil (1981) Nuclear Heat Transport, American Nuclear Society; First Edition, ISBN-13: 9780894480140 http://www.ans.org/store/item-350007/

[9] Frank P. Incropera ,David P. DeWitt, Theodore L. Bergman, (2006) Adrienne S. Lavine Fundamentals of Heat and Mass Transfer, 6th Edition, , John Wiley \& Sons; 6th edition, ISBN-13: 978-0471457282 http://uotechnology.edu.iq/depmaterials/lecture/secondclass/HeatTransfer\&FluidBOOKFrankPIncroperaFu ndamentalsofheatandmasstransfer2007.pdf 
[10] H.T El-Dessouky and H.M Ettouney (2002) Fundamentals of Salt Water Desalination, Elsevier Science, ISBN: 9780444508102

https://www.elsevier.com/books/fundamentals-of-salt-water-desalination/el-dessouky/978-0-444-50810-2

[11] I.S. Jaber and M.R. Ahmed, 2004, Technical and economic evaluation of brackish groundwater desalination by reverse osmosis (RO) process, Desalination, 165, 209-213. https://doi.org/10.1016/j.desal.2004.06.051

[12] D. Sambrailo, J. Ivic and A. Krstulovic, 2005, Eco-nomic evaluation of the first desalination plant in Croatia, Desalination, 170, 339-344. doi: $10.1016 /$ j.desal.0000.00.000

[13] A. Hafez and S. El-Manharawy, 2002, Economics of seawater RO desalination in the Red Sea region, Egypt. Part 1. A case study, Desalination, 153, 335-347. https://doi.org/10.1016/S0011-9164(02)01122-0

[14] E. Tzen and R. Morris, 2003, Renewable energy sources for desalination, Solar Energy, 75, 375-379. doi:10.1016/j.solener.2003.07.010

[15] E.S. Mohamed and G. Papadakis, Design, simula- tion and economic analysis of a stand-alone reverse osmosis desalination unit powered by wind turbines and photovoltaics, Desalination, 164, 87-97. DOI: $10.13140 /$ RG.2.1.3122.4807

[16] E.S. Mohamed, G. Papadakis, E. Mathioulakis and V. Belessiotis, 2005, The effect of hydraulic energy recovery in a small sea water reverse osmosis desalination system; experimental and economi- cal evaluation, Desalination, 184, 241-246. https://doi.org/10.1016/j.desal.2005.02.066

[17] Heat Transfer: Fundamentals and Applications, 5th Edition, Yunus A. Cengel and Michael A. Boles, McGraw-Hill Education; 5 edition (April 4, 2014), ISBN-13: 978-0073398181 https://www.academia.edu/28446752/Cengel_heat_and_mass_transfer_5ed

[18] J.R. Lamarsh and A.J. Baratta (2001) Introduction to Nuclear Engineering, Prentice Hall; 3rd edition (2001). http://www.gammaexplorer.com/wp-content/uploads/2014/03/Introduction-to-Nuclear-EngineeringLamarsh-3rd-Edition.pdf

[19] R. M. Mayo (1998) Introduction to Nuclear Concepts for Engineers. American Nuclear Society, USA https://www.amazon.com/Introduction-Nuclear-Concepts-Engineers-Robert/dp/0894484540

[20] Yunus A. Cengel , Michael A.Boles. (2014). Thermodynamics: An Engineering Approach McGraw-Hill Education; $\quad 8 \quad$ edition, $\quad$ ISBN-13: 9780073398174https://www.abebooks.com/9780073398174/Thermodynamics-Engineering-Approach-YunusCengel-0073398179/plp

[21] S.E. Hedayat, A.A. Sary., (1977) Design of a small single-purpose nuclear desalination plant compatible with local resources in the Middle East", Desalination, Vol. 20, No. 1977, pp. 257-266. https://inis.iaea.org/collection/NCLCollectionStore/ Public/09/419/9419193.pdf

[22] M. Methnani, R.Faibish., (2002) Status of design concept of nuclear desalination plants, IAEA-TECDOC1326. https://www.iaea.org/publications/6368/design-concepts-of-nuclear-desalination-plants

[23] T. Konishi., (2000). "Introduction of Nuclear Desalination", Technical Report Series No.400 (IAEA) DOI: 10.1504/IJND.2005.007010

[24] L. Tian, Y. Wang and J. Guo, 2002, Economic analysis of a $2 \times 200 \mathrm{MW}$ nuclear heating reactor for seawater desalination by multi-effect distillation (MED), Desalination, 152, 223-228. https://doi.org/10.1016/S0011-9164(02)01067-6

[25] R. Borsani and S. Rebagliati, 2005, Fundamentals and costing of MSF desalination plants and compari- son with other technologies, Desalination, 182, 29-37. https://doi.org/10.1016/j.desal.2005.03.007

[26] S. Wu, 2006, Analysis of water production costs of a nuclear desalination plant with a nuclear heating reactor coupled with MED processes, Desalina- tion, 190, 287-294.

https://www.uxc.com/p/products/rpt_smo.aspx

[27] G. Fiorenza, 2003, V.K. Sharma and G. Braccio, Techno- economic evaluation of a solar powered water desalination plant, Ener. Conv. Manag., 44, 2217-2240. doi:10.1016/S0196-8904(02)00247-9 